\title{
Subfoveal congenital hypertrophy of retinal pigment epithelium
}

\author{
Harsha Saxena, ${ }^{1}$ Brijesh Takkar, ${ }^{1}$ Varsha Shrivastava, ${ }^{1}$ Shorya Vardhan Azad ${ }^{2}$
}

'Department of Ophthalmology, All India Institute of Medical Sciences, Bhopal, Madhya Pradesh, India

${ }^{2}$ Dr. R. P. Center for Ophthalmic Sciences, All India Institute of Medical Sciences, New Delhi, Delhi, India

Correspondence to Dr Brijesh Takkar, britak.aiims@gmail.com

Accepted 12 June 2018
Check for updates

(c) BMJ Publishing Group Limited 2018. No commercial re-use. See rights and permissions. Published by BMJ.

To cite: Saxena H, Takkar B, Shrivastava V, et al. BMJ Case Rep Published Online First: [please include Day Month Year]. doi:10.1136/bcr-2018225845

\section{DESCRIPTION}

A 25-year-old man presented with slight blurring of vision in the right eye (RE), noted 3 years ago. There was no positive systemic history. His best corrected visual acuity was 6/9 in RE and 6/6 in the left eye (LE) at presentation. Anterior segment evaluation was unremarkable in both eyes with normal pupil light reflexes. Fundus evaluation revealed a flat circular lesion beneath the fovea, and was measured to be one-third of the size of the optic nerve head. It was a densely pigmented lesion, black in colour, with a surrounding depigmented whitish halo (figure 1). The LE was within normal range on clinical examination. Spectral domain optical coherence tomography (SD-OCT) of RE revealed the lesion to be irregular but flat with hyper-reflectivity at the level of the retinal pigment epithelium (RPE). Discontinuity of the ellipsoid zone was noted to be overlying some parts of the lesion. These findings were also accompanied by foci of intraretinal migration of the pigment epithelium within the outer nuclear layer and a subretinal cleft (figure 2). The central macular thickness was measured to be $252 \mu \mathrm{m}$. No consistent scotoma was detected on repeated charting with Amsler's grid. After careful literature review of OCT findings of hyperpigmented lesions, this lesion was labelled as subfoveal congenital hypertrophy of RPE (CHRPE) and was advised regular follow-up.

CHRPE is usually present in the peripheral fundus with nearly all demonstrating a perilesional halo. ${ }^{1}$ It may or may not have lacunae within it. Macular CHRPE is very rare, and subfoveal rarer still. ${ }^{12}$ It is believed to represent less than $1 \%$ of all the cases of CHRPE. ${ }^{2}$ Therefore, vision loss due to

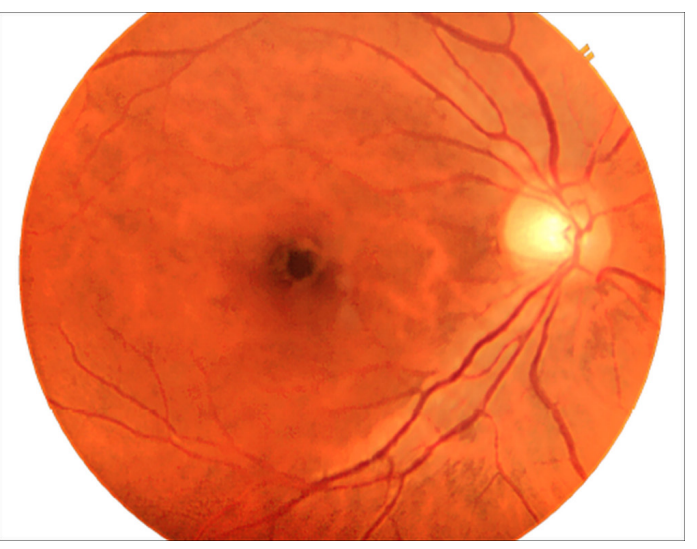

Figure 1 Fundus photograph of the right eye showing the well-defined flat subfoveal lesion. The lesion is densely pigmented and has a regular halo around it.

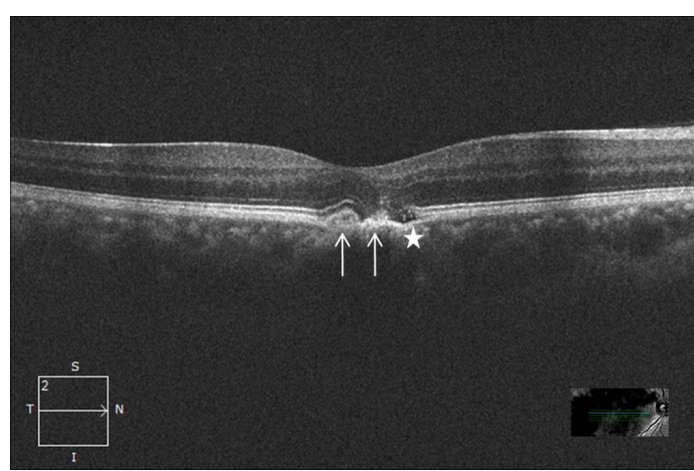

Figure 2 Spectral domain optical coherence tomography horizontal line scan through the lesion (seen in inset infrared image) showing hyper-reflectivity at the level of the retinal pigment epithelium (RPE) along with a thickened RPE layer (white arrows). Intraretinal migration of RPE, deficiency of ellipsoid layer and external limiting membrane, and a subretinal cleft are noticeable (star).

CHRPE is rare. A retrospective case series on OCT findings found these lesions to be flat with thickened and irregular RPE, with overlying neurosensory retina to be affected until the outer nuclear layer $(67 \%)$ in majority of the cases. Intraretinal findings included hyper-reflective foci along with subretinal clefts in the regions where outer retinal layers were disturbed. ${ }^{1}$ The authors describe subretinal fluid to be an absence of layers wherein the tissue appears to be retracted in a shallow manner. Photoreceptor loss has been repeatedly shown to be an important feature of CHRPE. ${ }^{1}$ All these features were present in our case too (figure 2).

Differential diagnosis of dark pigmented macular lesions includes haemorrhagic degenerations like polypoidal choroidal vasculopathy which is seen in older age groups. It is progressive in nature with raised lesions and choroidal changes with commonly accompanying subretinal fluid. Further, choroidal tumours like melanoma may also simulate these

\section{Learning points}

- Congenital hypertrophy of retinal pigment epithelium may rarely involve the subfoveal region and result in minor visual disturbance. The signs, however, are out of proportion to the symptoms.

- Knowledge of optical coherence tomography features helps in diagnosis and decreases the requirement of expensive and invasive investigations. 
lesions and vice versa. However, OCT features of these tumours have shown subretinal fluid accompanying dome-shaped lesions with shaggy photoreceptors. ${ }^{3}$ Thus apart from the clinical phenotype, knowledge of the OCT features aids in diagnosing uncommon presentations and obviates expensive and invasive investigations. Though the lesion looked ominous in this patient (figure 1), the visual loss was minor and stationary.

Contributors HS worked on the patient, performed imaging and did patient counselling. BT diagnosed the patient. BT, VS and HS wrote the manuscript. BT and SVA critically revised the manuscript.

Funding The authors have not declared a specific grant for this research from any funding agency in the public, commercial or not-for-profit sectors.
Competing interests None declared.

Patient consent Obtained.

Provenance and peer review Not commissioned; externally peer reviewed.

\section{REFERENCES}

1 Fung AT, Pellegrini M, Shields CL. Congenital hypertrophy of the retinal pigment epithelium: enhanced-depth imaging optical coherence tomography in 18 cases Ophthalmology 2014;121:251-6.

2 Kumar V, Chandra P, Kumar A. Macular congenital hypertrophy of retinal pigment epithelium (CHRPE) in a patient with best vitelliform dystrophy (BVD). BMJ Case Rep 2015;2015:bcr2015212832.

3 Shields CL, Pellegrini M, Ferenczy SR, et al. Enhanced depth imaging optical coherence tomography of intraocular tumors: from placid to seasick to rock and rolling topography-the 2013 Francesco Orzalesi Lecture. Retina 2014;34:1495-512.

Copyright 2018 BMJ Publishing Group. All rights reserved. For permission to reuse any of this content visit http://group.bmj.com/group/rights-licensing/permissions.

BMJ Case Report Fellows may re-use this article for personal use and teaching without any further permission.

Become a Fellow of BMJ Case Reports today and you can:

- Submit as many cases as you like

- Enjoy fast sympathetic peer review and rapid publication of accepted articles

- Access all the published articles

- Re-use any of the published material for personal use and teaching without further permission

For information on Institutional Fellowships contact consortiasales@bmjgroup.com

Visit casereports.bmj.com for more articles like this and to become a Fellow 